Pak. J. Agri. Sci., Vol. 55(1), 191-196;2018

ISSN (Print) 0552-9034, ISSN (Online) 2076-0906

DOI: 10.21162/PAKJAS/18.6547

http://www.pakjas.com.pk

\title{
COMPOSITIONAL ANALYSIS OF PAKISTANI GREEN AND RED CABBAGE
}

\author{
Faiza Ashfaq ${ }^{1}$ *, Masood Sadiq Butt ${ }^{1}$, Akmal Nazir ${ }^{1}$ and Amer Jamil ${ }^{2}$ \\ ${ }^{1}$ National Institute of Food Science and Technology, University of Agriculture, Faisalabad, Pakistan; \\ ${ }^{2}$ Department of Biochemistry, University of Agriculture, Faisalabad, Pakistan. \\ "Corresponding author's e-mail: kahloonfazi@yahoo.com
}

\begin{abstract}
Nowadays, vegetables are gaining attention amongst the masses to mitigate lifestyle related dysfunctions owing to their safe nature and functional properties. Considering health benefits and cost-effectiveness of cabbage, the current research was designed to investigate the proximate composition and mineral profile of locally grown green and red cabbage. Comparative compositional characterization of green and red cabbage indicated significantly higher amounts of crude protein, crude fat, crude fiber and ash content in red cabbage as compared to green cabbage due to non-momentously lower content of moisture in red cabbage. However, on fresh weight basis, moisture was the major constituent differing from $89.84 \pm 4.04$ to $91.29 \pm 4.29$ g/100g F.W. trailed by nitrogen free extract, crude fiber, crude protein, ash and crude fat. Moreover, most of the minerals like potassium, calcium, sodium, iron, copper, cobalt and manganese were on higher side in red cabbage except magnesium, zinc and copper. However, potassium was the most abundant mineral in both cabbage samples varying between 53.42 \pm 1.87 $96.44 \pm 3.38 \mathrm{mg} / 100 \mathrm{~g}$ F.W. followed by magnesium and calcium, ranged from $20.61 \pm 0.99$ to $22.60 \pm 0.81$ and $19.88 \pm 1.29$ to $20.56 \pm 1.11 \mathrm{mg} / 100 \mathrm{~g}$ F.W., respectively. In the nutshell, red cabbage has shown better nutritional value, thus this knowledge need to be disseminated among the masses to change their dietary preference. As a response, vegetable growers in Pakistan should focus on the production of red cabbage over green equivalent.
\end{abstract}

Keywords: Brassica oleracea L., vegetables, free radicals, antioxidants, dietary fiber.

\section{INTRODUCTION}

Earlier surveys have inversely associated the sufficient intakes of vegetables and legumes with diseases owing to the presence of biologically active ingredients including dietary fiber, phytoceutics and minerals that aid in preventing uncontrolled free radicals (Hussein, 2012; Assad et al., 2014; Ji et al., 2015; Ashraf et al., 2016; Raza et al., 2017). Previously, these dietary approaches have also shown their defensive potential against oncogenic events. Amongst various vegetables, brassica vegetables like cabbage, cauliflower, broccoli, brussels, etc. contribute positively towards nutrition and health perspectives (Oerlemans et al., 2006; Singh et al., 2007; Bacchetti et al., 2014).

Cabbage (Brassica oleracea L.) is an important crop, belongs to family Cruciferae or Brassicaceae containing abundant proportions of fiber, vitamins, minerals and health boosting compounds. Pakistan is an agricultural economy, cultivating various types of fruits and vegetables. Recently, approx. 77233 tons of cabbage was cultivated on an area of 4983 hectares in Pakistan (GOP, 2016). The most familiar varieties of cabbage include green, red, Chinese and savoy (Khan et al., 2014). Due to the difference in soil conditions, red cabbage is sometimes having purple color hence also named as purple cabbage. It is a fall/winter crop i.e. native to southern Europe where it is being employed in numerous cuisines. It possesses crunchiness along with sweet and peppery taste; however, for optimum organoleptic features, it is cultivated in cold environments (Draghici et al., 2013; Assad et al., 2014).

Recently, crucifers have gained renewed interest with special reference to ample amount of minerals such as $\mathrm{K}, \mathrm{Fe}, \mathrm{Mg}$ and $\mathrm{Mn}$; involve in cardiac health and co-factor of Mn-SOD i.e. an endogenous antioxidant enzyme. Besides, these vegetables are also considered as a rich source of dietary fiber, phytoceutics and antioxidant vitamins (Vallejo et al., 2004; Podsędek et al., 2006; Jeffery and Araya, 2009; Amnah, 2013; Al-Dosari, 2014; Park et al., 2014; Abbas et al., 2017). Furthermore, previous researchers disclosed the mineral profile of raw and cooked common cabbage that reflected higher amounts of potassium followed by calcium, magnesium and sodium, whereas trace amounts of iron, manganese, copper and zinc were also detected. Interestingly, it is documented that calcium absorption from cabbage is higher owing to the existence of organic acids like malic and citric acids (Kawashima and Soares, 2003). Besides, cabbage juice is considered as a rich source of potassium that could fulfill $17 \%$ of the daily requirement hence maintains body's fluid balance especially for those who consume higher amounts of sodium in their diet or facing nutrient malabsorption. Apart from this, calcium fulfills 19\% of 1000 $\mathrm{mg}$ of daily suggested intake, contributing structure to bones and teeth. Furthermore, the presence of selenium in cabbage is attributed to enhance immune responses. Considering $\mathrm{Fe}$, the shredded green and red cabbage could supply 2 and $3 \%$ of the daily value, maintaining red blood cells function i.e. 
carrying oxygen to all the cells ultimately protecting from anemia (Priya, 2012). Such an indication of minerals should need to be assessed in Pakistani cultivars because large variations exist from country to country, on the basis of genome or environment (Gaafar et al., 2014).

In this context, Pakistani green and red cabbages were scrutinized to highlight the nutritive value of these vegetables.

\section{MATERIALS AND METHODS}

The present research was carried out at the Faculty of Food, Nutrition \& Home Sciences, University of Agriculture, Faisalabad (UAF), Pakistan. In the current investigation, locally grown green and red cabbages were procured to assess their compositional and antioxidant status.

Procurement and preparation of raw materials: The green cabbage (variety: Ever Green F1) and red cabbage (variety: Red Globe), Botanical name: Brassica oleracea var. capitata were procured from Ayub Agriculture Research Institute (AARI), Faisalabad, Pakistan. The cabbage samples were randomly selected on the basis of quality attributes; color, head size and free from any visual defects and washed to remove foreign matters and other impurities followed by refrigeration prior to experimentation. The reagents and standards were acquired from different companies whose details and catalogue numbers are given.

Compositional analysis: The cabbage samples were analyzed for proximate composition and their brief descriptions are given below:

Moisture content: The percentage moisture in cabbage samples was measured using Method No. 934-01 (AOAC, 2006). Accordingly, $5 \mathrm{~g}$ fresh cabbage sample was dried at $105 \pm 5^{\circ} \mathrm{C}$ in Air Forced Draft Oven (Model: DO-1-30/02, PCSIR, Pakistan) till weight became constant. Afterwards, moisture content in cabbage samples was calculated by following expression;

Moisture $(\%)=\frac{\text { Fresh cabbage weight }(\mathrm{g})-\text { Dried cabbage weight }(\mathrm{g})}{\text { Fresh cabbage weight }(\mathrm{g})} \times 100$

Crude protein: The crude protein in cabbage samples was quantified using Method No. 984-13 via Kjeltech Apparatus; Model: D-40599, Behr Labor Technik, GmbH-Germany (AOAC, 2006). Purposely, dried cabbage sample was digested through conc. $\mathrm{H}_{2} \mathrm{SO}_{4}$ (Sigma-Aldrich, Japan Cat \# 339741) plus digestion tablets from AppliChem, Germany Cat \# A7734 (K $\mathrm{K}_{2} \mathrm{SO}_{4}: \mathrm{FeSO}_{4}: \mathrm{CuSO}_{4}$ 100:5:10; to prevent from splashing) till light greenish color, achieved after three to four hours. After digestion, the material was diluted up to $250 \mathrm{~mL}$. For distillation, the digested diluted material $(10 \mathrm{~mL})$ was treated with $10 \mathrm{~mL}$ of $40 \% \mathrm{NaOH}$ (Sigma-Aldrich, Japan Cat \# 221465) via distillation assembly. The released $\mathrm{NH}_{3}$ was trapped in $4 \%$ boric acid solution containing methyl red (indicator), forming ammonium borate that expresses nitrogen content. Finally, the distillate was titrated against 0.1 $\mathrm{N} \mathrm{H}_{2} \mathrm{SO}_{4}$ till light golden color and volume was noted. The crude protein $(\%)$ in the sample was estimated by multiplying percent nitrogen (N\%) with correction factor (5.65) using following formula;

$$
\mathrm{N}(\%)=\frac{\mathrm{H}_{2} \mathrm{SO}_{4} \text { volume used } \times 0.0014 \times 250 \mathrm{~mL} \text { (dilution volume) }}{\text { Initial sample weight } \times \text { Diluted sample volume taken }} \times 100
$$

Crude fat: The crude fat in dried samples was determined using Method No. 920-39 via Soxhlet System; Model: H-2 1045 Extraction Unit, Hoganas, Sweden (AOAC, 2006). For maximum fat extraction, dried cabbage powder $(5 \mathrm{~g})$ was given five to six siphoning washes, continuously using nhexane (MP Biomedicals, USA Cat \# 02195220) by regulating flow rate; $3-4$ drops/second followed by sample drying at $105 \pm 5^{\circ} \mathrm{C}$. The crude fat measured was expressed as loss in sample weight.

Crude fat $(\%)=$

Dried cabbage weight $(\mathrm{g})$ - Dried \& defatted cabbage weight $(\mathrm{g})$ Dried cabbage sample weight $(\mathrm{g})$

Crude fiber: The crude fiber was measured using Method No. 978-10 (AOAC, 2006). Accordingly, dried and defatted cabbage sample $\left(2 \mathrm{~g}\right.$ ) was digested with boiling $1.25 \% \mathrm{H}_{2} \mathrm{SO}_{4}$ (200 $\mathrm{mL}$ ) for $30 \mathrm{~min}$ in Labconco Fibertech apparatus (Labconco Corporation Kansas, USA). After draining the acid, digested sample was filtered followed by washing with boiling distilled water to make it acid free. Later, the resultant sample was treated with $1.25 \% 200 \mathrm{~mL}$ of boiling $\mathrm{NaOH}$ solution for $30 \mathrm{~min}$ to remove all base solubilized fractions. Again filtration and washing procedure was repeated, remaining residues (containing crude fiber and ash) were dried at $130^{\circ} \mathrm{C}$ for $2 \mathrm{hr}$ followed by weighing $\left(\mathrm{W}_{1}\right)$ and ignition in Muffle Furnace ((MF-1/02, PCSIR, Pakistan; $550 \pm 15^{\circ} \mathrm{C}$ ) till whitish grey ash. After cooling, reweighed the ash achieved $\left(\mathrm{W}_{2}\right)$. The percent crude fiber was calculated using formula given below;

Crude fiber $(\%)=$

Dried sample weight after digestion $\mathrm{W}_{1}(\mathrm{~g})$ - Ash weight $\mathrm{W}_{2}(\mathrm{~g}) \times 100$ Dried \& defatted sample weight ( $\mathrm{g}$ )

Ash content: The inorganic residues in cabbage samples were estimated Method No. 942-05 (AOAC, 2006). Purposely, 5 g cabbage powder was charred on flame in crucible until fumeless trailed by ignition in muffle furnace $\left(550 \pm 15^{\circ} \mathrm{C}\right)$ till whitish grey residues were attained (5-6 hr).

$$
\text { Ash }(\%)=\frac{\text { Weight of whitish grey residues after ignition }(\mathrm{g})}{\text { Initial weight of dried cabbage }(\mathrm{g})} \times 100
$$

Nitrogen free extract (NFE): The nitrogen-free extract in cabbage samples was calculated by using equation as under; NFE $(\%)=100-($ moisture + crude protein + crude fat + crude fiber + ash $) \%$

Mineral profile: Minerals like Ca (Sigma-Aldrich, Japan Cat \# 21049), K (AppliChem, Germany Cat \# 313190) and $\mathrm{Na}$ (AppliChem, Germany Cat \# 313192) were detected via Flame Photometer-410; Sherwood Scientific Ltd., Cambridge, UK using Method no 956.01 while $\mathrm{Mg}$ (AppliChem, Germany Cat \# 313184), Fe (AppliChem, Germany Cat \# 313182), Zn (AppliChem, Germany Cat \# 
313193), Mn (Merck, Germany Cat \# 119789), Co (AppliChem, Germany Cat \# 313177) and Cu (AppliChem, Germany Cat \# 313178) through Atomic Absorption Spectrophotometer; Hitachi Polarized Zeeman AAS, Z-8200, Japan using Method no 975.03 (b) and 991.11 (AOAC, 2006). In this context, dried cabbage $(0.5 \mathrm{~g})$ was wet digested using di-acid system; nitric acid: perchloric acid (7:3) from SigmaAldrich, Japan Cat \# 438073 \& 311421, respectively on hot plate till 1 to $2 \mathrm{~mL}$ of solution left. Afterwards, dilution up to $100 \mathrm{~mL}$ was made followed by characterization using their respective system.

Statistical analysis: The resultant data from each parameter were subjected to statistical modeling through completely randomized design (CRD) using Statistix 8.1. Furthermore, level of significance was also estimated $(p<0.05 \& p<0.01)$ by using analysis of variance (ANOVA) technique followed by Tukey's HSD multiple comparison tests for means separation (Mason et al., 2003).

\section{RESULTS}

The compositional analysis is an imperative tool to assess the nutritive value of food commodities. According to Table 1 the moisture content was found slightly higher in green cabbage $91.29 \pm 4.29 \mathrm{~g} / 100 \mathrm{~g}$ F.W. than red cabbage $89.84 \pm 4.04 \mathrm{~g} / 100 \mathrm{~g}$ F.W. Resultantly, other components including crude protein, crude fat, crude fiber, ash and NFE were found significantly higher in red cabbage as compared to green counterpart, ranging from $0.92 \pm 0.03$ to $1.21 \pm 0.05,0.02 \pm 0.01$ to $0.04 \pm 0.00,2.95 \pm 0.11$ to $3.49 \pm 0.17,0.69 \pm 0.01$ to $0.87 \pm 0.03$ and $4.13 \pm 0.14$ to $4.55 \pm 0.17 \mathrm{~g} / 100 \mathrm{~g}$ F.W. correspondingly.

Table 1. Compositional profiling of cabbage.

\begin{tabular}{lcc}
\hline $\begin{array}{l}\text { Proximate composition } \\
\text { (g/100g F.W.) }\end{array}$ & Green cabbage & Red cabbage \\
\hline Moisture & $91.29 \pm 4.29$ & $89.84 \pm 4.04$ \\
Crude protein & $0.92 \pm 0.03^{\mathrm{b}}$ & $1.21 \pm 0.05^{\mathrm{a}}$ \\
Crude fat & $0.02 \pm 0.01^{\mathrm{b}}$ & $0.04 \pm 0.00^{\mathrm{a}}$ \\
Crude fiber & $2.95 \pm 0.11^{\mathrm{b}}$ & $3.49 \pm 0.17^{\mathrm{a}}$ \\
Ash & $0.69 \pm 0.01^{\mathrm{b}}$ & $0.87 \pm 0.03^{\mathrm{a}}$ \\
Nitrogen free extract & $4.13 \pm 0.14^{\mathrm{b}}$ & $4.55 \pm 0.17^{\mathrm{a}}$ \\
\hline
\end{tabular}

Data values represent mean \pm SD $(n=3)$; Means carrying same letters do not differ significantly.

Moreover, statistical inference indicated that minerals including potassium, sodium, iron, cobalt and manganese differed momentously in both cabbages however, on higher side in red cabbage 96.44 $\pm 3.38,12.33 \pm 0.55,1.11 \pm 0.04$, $0.20 \pm 0.01 \& 0.18 \pm 0.01 \mathrm{mg} / 100 \mathrm{~g}$ F.W. than green cabbage $53.42 \pm 1.87,9.87 \pm 0.39,0.75 \pm 0.03,0.14 \pm 0.00 \& 0.12 \pm 0.01$ $\mathrm{mg} / 100 \mathrm{~g}$ F.W., respectively. Furthermore, calcium, magnesium, zinc and copper explicated non-significant variations with respect to both cabbages though, calcium was detected more in red cabbage $20.56 \pm 1.11 \mathrm{mg} / 100 \mathrm{~g} \mathrm{~F}$.W. than green equivalent $19.88 \pm 1.29 \mathrm{mg} / 100 \mathrm{~g}$ F.W., whereas magnesium, zinc and copper were quantified relatively more in green cabbage $22.6 \pm 0.81,0.31 \pm 0.01 \& 0.05 \pm 0.00 \mathrm{mg} / 100 \mathrm{~g}$ F.W. as compared to red cabbage $20.56 \pm 0.99,0.29 \pm 0.01$ and $0.04 \pm 0.00 \mathrm{mg} / 100 \mathrm{~g}$ F.W., accordingly (Table 2).

Table 2. Mineral content of cabbage.

\begin{tabular}{lcc}
\hline $\begin{array}{l}\text { Minerals } \\
\text { (mg/100g F.W.) }\end{array}$ & Green cabbage & Red cabbage \\
\hline Potassium (K) & $53.42 \pm 1.87^{\mathrm{b}}$ & $96.44 \pm 3.38^{\mathrm{a}}$ \\
Calcium $(\mathrm{Ca})$ & $19.88 \pm 1.29$ & $20.56 \pm 1.11$ \\
Magnesium $(\mathrm{Mg})$ & $22.60 \pm 0.81$ & $20.61 \pm 0.99$ \\
Sodium $(\mathrm{Na})$ & $9.87 \pm 0.39^{\mathrm{b}}$ & $12.33 \pm 0.55^{\mathrm{a}}$ \\
Iron $(\mathrm{Fe})$ & $0.75 \pm 0.03^{\mathrm{b}}$ & $1.11 \pm 0.04^{\mathrm{a}}$ \\
Zinc $(\mathrm{Zn})$ & $0.31 \pm 0.01$ & $0.29 \pm 0.01$ \\
Copper $(\mathrm{Cu})$ & $0.05 \pm 0.00$ & $0.04 \pm 0.00$ \\
Cobalt $(\mathrm{Co})$ & $0.14 \pm 0.00^{\mathrm{b}}$ & $0.20 \pm 0.01^{\mathrm{a}}$ \\
Manganese $(\mathrm{Mn})$ & $0.12 \pm 0.01^{\mathrm{b}}$ & $0.18 \pm 0.01^{\mathrm{a}}$ \\
\hline
\end{tabular}

Data values represent mean $\pm \operatorname{SD}(n=3)$; Means carrying same letters do not differ significantly

\section{DISCUSSION}

The current results are in close harmony with the work of previous researchers, who measured crude fiber, carbohydrate, fat, protein, ash and NFE in white, green or common cabbage, varying between 21.64-33.31, 62-71.26, $0.52-4.4,14.3-30.09,5.82-10.5$ and $35.12 \%$ D.W., whereas in red cabbage, the said traits were reported as 14.61-44.87, $64.54,0.85,13.99-26.67,9.77$ and $17.84 \%$ on dry weight basis, respectively. The total dietary fiber in dried cabbage was found to be varying from 27.3 to $29.9 \%$; however, the moisture content in fresh red cabbage was varying from 91.0 to $91.7 \%$ (Wu et al., 2006; Kahlon et al., 2007; Kahlon et al., 2008; PeñAs et al., 2010; Hussein, 2012; Amnah, 2013; Mohammed and Luka, 2013). Previously, the compositional profile of outer leaves of cabbage portrayed protein $18.43 \pm 0.60 \%$, lipid $1.02 \pm 0.11 \%$, ash $9.02 \pm 0.90 \%$, carbohydrate $30.46 \pm 0.99 \%$ and total dietary fiber $40.89 \pm 2.25 \%$; soluble dietary fiber $7.35 \pm 0.81 \%$ and insoluble dietary fiber; $33.54 \pm 1.44 \%$ on dry mass basis (Tanongkankit et al., 2012). Earlier scrutiny documented that cabbage possesses approx. $4.6 \mathrm{~g}$ carbohydrate, $1.8 \mathrm{~g}$ protein, $0.1 \mathrm{~g}$ fat, $0.6 \mathrm{~g}$ minerals and $36.6 \mathrm{mg}$ vitamin C, $98 \mathrm{IU}$ vitamin A \& 76 $\mu \mathrm{g}$ vitamin K per $100 \mathrm{~g}$ F.W. (Tiwari et al., 2003; Park et al., 2014). The ranges of almost all attributes in the aforementioned studies are covering the data obtained in the current investigation.

In another attempt, the compositions of fresh and blanched cabbage samples were compared by Nilnakara et al. (2009). The study outcomes presented protein, crude fat, crude fiber, ash and carbohydrates in fresh \& blanched cabbage as $19.48 \pm 0.19 \& 21.15 \pm 0.02, \quad 0.97 \pm 0.06 \quad \& \quad 1.85 \pm 0.05$, $19.92 \pm 1.08 \& 47.47 \pm 3.34,7.82 \pm 0.38 \quad \& \quad 5.26 \pm 0.18$ and 
$51.36 \pm 1.89 \& 24.61 \pm 1.11 \%$ on dry weight basis, accordingly These findings are also in corroboration with the results of the instant study. Mostly in dieting programs, cabbage is given a major share in the diet plan being low in calories (Al-Dosari, 2014). The calories content in brassica vegetables as reported by Heimler et al. (2006) were approx. $24-34 \mathrm{kcal} / 100 \mathrm{~g}$ as the protein, fat and fiber were $1.44-2.82,0.12-0.37$ and $2.5 \mathrm{~g}$ per 100 g F.W., respectively.

Considering mineral characterization, the green cabbage consumed in southern Brazil, raw and cooked counterparts were analyzed for minerals (mg/100g F.W.) and finding disclosed higher amounts of potassium $266 \pm 87 \& 275 \pm 103$ followed by calcium $44 \pm 6 \& 46 \pm 5$, magnesium $14 \pm 2 \& 15 \pm 3$ and sodium $3 \pm 1 \& 3 \pm 1$. This study found $\mathrm{K} \& \mathrm{Ca}$ were on the higher side, whereas $\mathrm{Mg}$ and $\mathrm{Na}$ were quantified lesser than the outcomes of the current exploration. Furthermore, trace minerals like iron $0.14 \pm 0.03 \& 0.16 \pm 0.04$, manganese $0.2 \pm 0.1 \& 0.2 \pm 0.1$, copper $0.05 \pm 0.05 \& 0.04 \pm 0.04$ and zinc $0.2 \pm 0.1 \& 0.2 \pm 0.1$ were nearly within the ranges as noted in the present study. After cooking, the percent increase in potassium was $7 \%$ whilst, percent decrease in rest of the minerals was observed as sodium 21 , calcium 2 , magnesium 2, iron 1, manganese 11, copper 3 and zinc 5 (Kawashima and Soares, 2003). Recently, Malav et al. (2015) reported calcium content in cabbage up to $45 \mathrm{mg} / 100 \mathrm{~g}$ F.W. that was higher than the current study result. Similarly, another researcher reported calcium content in green cabbage in the range of 45 to $106 \mathrm{mg} / 100 \mathrm{~g}$ F.W. Furthermore, he noted higher calcium content in outer leaves of cabbage; 476 to $998 \mathrm{mg} / 100 \mathrm{~g} \mathrm{~F}$.W. as compared to inner yellowish leaves, varying from 26 to 53 $\mathrm{mg} / 100 \mathrm{~g}$ F.W. (Cowell, 1932).

The outcomes of the current research are also comparable to previous studies that reported $\mathrm{Ca} 29, \mathrm{Fe} 0.8$ and $\mathrm{Na} 14.1$ $\mathrm{mg} / 100 \mathrm{~g}$ F.W. in common cabbage (Tiwari et al., 2003; Park et al., 2014). Furthermore, the current data is in agreement with the results presented by Lucarini et al. (2000), they determined iron and zinc in green cabbage as $0.71 \pm 0.23$ and $0.53 \pm 0.12 \mathrm{mg} / 100 \mathrm{~g}$, respectively. In a research work, Zarembski and Hodgkinson (1962) measured the $\mathrm{Ca}, \mathrm{Mg}$ and P contents in cabbage, ranging from 19.5 to $87.7,11.6$ to 2.6 and 13.9 to $97.6 \mathrm{mg} / 100 \mathrm{~g} \mathrm{F.W.,} \mathrm{correspondingly.} \mathrm{Moreover,}$ Warman and Havard (1997) analyzed conventional \& organic cabbage samples and found $\mathrm{Ca} 341$ to 603 \& 312 to 614 $\mathrm{mg} / 100 \mathrm{~g}$ D.W., whereas $\mathrm{Mg} 125$ to 144 \& 125 to 154 $\mathrm{mg} / 100 \mathrm{~g} \mathrm{D} . W$. and $\mathrm{Cu}$ as $19 \& 42 \mathrm{mg} / 100 \mathrm{~g}$ D.W. in the respective samples. Later, Mohammed and Luka (2013) compared the green $\&$ red cabbage for different minerals like calcium and phosphorous. They noted values for the said minerals as $1.76 \pm 0.04 \& 0.96 \pm 0.09$ and $0.86 \pm 0.09$ \& $1.89 \pm 0.19 \mathrm{mg} / 100 \mathrm{~g}$ D.W. in green \& red cabbage, respectively that were far lower than results obtained in the current study. One of their peers, Draghici et al. (2013) found $\mathrm{Ca}$ and $\mathrm{Mg}$ in white cabbage as 40 and $12 \mathrm{mg} / 100 \mathrm{~g}$ F.W., respectively. Although, earlier studies highlighted the rich nutritive value of cruciferous vegetables but differences exist based on geographical location \& soil condition, types and cultivars of cabbage, use of fertilizers, etc.

Conclusions: In the nutshell, cabbage grown in Pakistan possesses splendid nutritional and health perspectives. Furthermore, their inclusion in our daily routine could suffice the basic needs of the body in terms of minerals and fiber content besides protection from various free radicals induced malfunctions. Alongside, its consumption during summer season keeps the body hydrating owing to the presence of higher water content. Thus, such nutritious, approachable and cost-effective vegetables should be encouraged by the consumers. Alongside, industrialists should need to incorporate these vegetables in the recipes of existing conventional food products to replenish their nutritional value. Domestically, such studies would go a long way in guiding the vegetable growers to cultivate red cabbage in abundance.

\section{REFERENCES}

Abbas, M., S. Farhan, F.M. Anjum, M. Afzaal, T. Tufail, M.S. Bashir, A. Ishtiaq, S. Hussain and H.A.R. Suleria. 2017. Natural polyphenols: An overview. Int. J. Food Prop. 20:1689-1699.

Al-Dosari, M.S. 2014. Red cabbage (Brassica oleracea L.) mediates redox-sensitive amelioration of dyslipidemia and hepatic injury induced by exogenous cholesterol administration. Am. J. Chin. Med. 42:189-206.

Amnah, M.A.A. 2013. Hypoglycemic and hypolipidemic activities of red cabbage and manganese in diabetic rats. J. Am. Sci. 9:13-19.

AOAC. 2006. Official Methods of Analysis of Association of Official Analytical Chemists International. In: W. Horwitz, $18^{\text {th }}$ Ed. AOAC Press, Arlington, VA, USA.

Ashraf, H., M.S. Butt, A. Asghar and M. Shahid. 2016. Comparative study of conventional solvent and supercritical fluid extracts of turmeric using high performance liquid chromatography. Pak. J. Agri. Sci. 53:941-946.

Assad, T., R.A. Khan and Z. Feroz. 2014. Evaluation of hypoglycemic and hypolipidemic activity of methanol extract of Brassica oleracea. Chin. J. Nat. Med. 12:648653.

Bacchetti, T., D. Tullii, S. Masciangelo, R. Gesuita, E. Skrami, F. Brugè, S. Silvestri, P. Orlando, L. Tiano and G. Ferretti. 2014. Effect of black and red cabbage on plasma carotenoid levels, lipid profile and oxidized low density lipoprotein. J. Funct. Foods. 8:128-137.

Cowell, S.J. 1932. A note on the calcium content of cabbage. Biochem. J. 26:1422-1423.

Draghici, G., L.M. Alexandra, B. Aurica-Breica, D. Nica, S. Alda, A. Liana, I. Gogoasa, I. Gergen and B. Despina- 
Maria. 2013. Red cabbage, millennium's functional food. J. Hort. Forest. Biotech. 17:52-55.

Gaafar, A.A., H.F. Aly, Z.A. Salama and N.Z. Mohamed. 2014. Hypoglycemic effects of white cabbage and red cabbage (Brassica oleracea) in STZ induced type-2 diabetes in rats. World J. Pharm. Sci. 3:1583-1610.

Government of Pakistan. 2016. Fruit, vegetables and condiments statistics of Pakistan. Ministry of Food Security and Research. Government of Pakistan. pp. 1112.

Heimler, D., P. Vignolini, M.G. Dini, F.F. Vincieri and A. Romani. 2006. Antiradical activity and polyphenol composition of local Brassicaceae edible varieties. Food Chem. 99:464-469.

Hussein, E. 2012. Potential therapeutic effects of dried cabbage and eggplant on hypercholestromic rat. Food Chem. 96:572-579.

Jeffery, E.H. and M. Araya. 2009. Physiological effects of broccoli consumption. Phytochem. Rev. 8:283-298.

Ji, C., C. Li, W. Gong, H. Niu and W. Huang. 2015. Hypolipidemic action of hydroxycinnamic acids from cabbage (Brassica oleracea L. var. capitata) on hypercholesterolaemic rat in relation to its antioxidant activity. J Food Nutr. Res. 3:317-324.

Kahlon, T., M. Chapman and G. Smith. 2007. In vitro binding of bile acids by spinach, kale, brussels sprouts, broccoli, mustard greens, green bell pepper, cabbage and collards. Food Chem. 100:1531-1536.

Kahlon, T.S., M.C.M. Chiu and M.H. Chapman. 2008. Steam cooking significantly improves in vitro bile acid binding of collard greens, kale, mustard greens, broccoli, green bell pepper, and cabbage. Nutr. Res. 28:351-357.

Kawashima, L.M. and L.M.V. Soares. 2003. Mineral profile of raw and cooked leafy vegetables consumed in Southern Brazil. J. Food Compost. Anal. 16:605-611.

Khan, R.A., Z. Feroz, M. Jamil and M. Ahmed. 2014. Hypolipidemic and antithrombotic evaluation of Myrtus communis L. in cholesterol-fed rabbits. Afr. J. Pharm. Pharmacol. 8:235-239.

Lucarini, M., G.D. Lullo, M. Cappelloni and G. LombardiBoccia. 2000. In vitro estimation of iron and zinc dialysability from vegetables and composite dishes commonly consumed in Italy: Effect of red wine. Food Chem. 70:39-44.

Malav, O.P., B.D. Sharma, R.R. Kumar, S. Talukder, S.R. Ahmed and A. Irshad. 2015 Antioxidant potential and quality characteristics of functional mutton patties incorporated with cabbage powder. Nutr. Food Sci. 45:542-563.

Mason, R.L., R.F. Gunst and J.L. Hess. 2003. Statistical design and analysis of experiments: With applications to engineering and science. John Wiley \& Sons, Inc., Hoboken, NJ, USA.
Mohammed, A. and C.D. Luka. 2013. Comparative analysis of the different Brassica oleracea varieties grown on Jos, plateau using albino rats. IOSR J. Pharm. Biol. Sci. 6:8588.

Nilnakara, S., N. Chiewchan and S. Devahastin. 2009. Production of antioxidant dietary fibre powder from cabbage outer leaves. Food Bioprod. Process. 87:301307.

Oerlemans, K., D.M. Barrett, C.B. Suades, R. Verkerk and M. Dekker. 2006. Thermal degradation of glucosinolates in red cabbage. Food Chem. 95:19-29.

Park, S., M.V. Arasu, M.K. Lee, J.H. Chun, J.M. Seo, S.W. Lee, N.A. Al-Dhabi and S.J. Kim. 2014. Quantification of glucosinolates, anthocyanins, free amino acids, and vitamin $\mathrm{C}$ in inbred lines of cabbage (Brassica oleracea L.). Food Chem. 145:77-85.

PeñAs, E., J. Frias, B. Sidro and C.N. Vidal-Valverde. 2010. Chemical evaluation and sensory quality of sauerkrauts obtained by natural and induced fermentations at different $\mathrm{NaCl}$ levels from Brassica oleracea var. capitata $c v$. Bronco grown in eastern Spain: Effect of storage. J. Agric. Food Chem. 58:3549-3557.

Podsędek, A., D. Sosnowska, M. Redzynia and B. Anders. 2006. Antioxidant capacity and content of Brassica oleracea dietary antioxidants. Int. J. Food Sci. Technol. 41:49-58.

Priya, S.L.S. 2012. Cabbage- A wonderful and awesome remedy for various ailments. Res. Pharm. Sci. 1:28-34.

Raza, A., M.S. Butt, I.U. Haq and H.A.R. Suleria. 2017. Jamun (Syzygium cumini) seed and fruit extract attenuate hyperglycemia in diabetic rats. Asian Pac. J. Trop. Biomed. 7:750-754.

Singh, J., A.K. Upadhyay, K. Prasad, A. Bahadur and M. Rai. 2007. Variability of carotenes, vitamin C, E and phenolics in Brassica vegetables. J. Food Compost. Anal. 20:106-112.

Tanongkankit, Y., N. Chiewchan and S. Devahastin. 2012. Physicochemical property changes of cabbage outer leaves upon preparation into functional dietary fiber powder. Food Bioprod. Process 90:541-548.

Tiwari, K., A. Singh and P. Mal. 2003. Effect of drip irrigation on yield of cabbage (Brassica oleracea L. var. capitata) under mulch and non-mulch conditions. Agric. Water Manage. 58:19-28.

Vallejo, F., F.A. Tomás-Barberán and F. Ferreres. 2004. Characterisation of flavonols in broccoli (Brassica oleracea L. var. italica) by liquid chromatography-UV diode-array detection-electrospray ionisation mass spectrometry. J. Chromat. 1054:181-193.

Warman, P.R. and K. Havard. 1997. Yield, vitamin and mineral contents of organically and conventionally grown carrots and cabbage. Agric. Ecosyst. Environ. 61:155-162. 
Wu, X., G.R. Beecher, J.M. Holden, D.B. Haytowitz, S.E. Gebhardt and R.L. Prior. 2006. Concentrations of anthocyanins in common foods in the United States and estimation of normal consumption. J. Agric. Food Chem. 54:4069-4075.

Zarembski, P. and A. Hodgkinson. 1962. The determination of oxalic acid in food. Anal. 87:698-702. 